\title{
AMAR
}

AMAR (Andalas Management Review)

Vol. 3, No. 2 (2019) 44-53

The Management Institute, Faculty of Economics, Universitas Andalas

ISSN (Print) 2476-9282 | ISSN (Online) 2548-155X

\section{The Branding of Padang City: How Does It Affect The City Image and Tourist Visit Decision?}

\author{
Heru Aulia Azmana, Monica Tuti Suryanib, Ares Albirru Amsalc \\ $a, b$ Department of Management Universitas Dharma Andalas, \\ heruaulia@yahoo.com,monicatuti@gmail.com \\ cDepartment of Management Universitas Andalas, aresalbirruamsal@eb.unand.ac.id
}

\begin{abstract}
Padang has widely known as the tourism destination in Indonesia. This city is the capital of West Sumatera Province which win three World Halal Tourism Award categories in 2016; World's Best Halal Culinary Destination, World's Best Halal Destination and Halal World's Best Tour Operator. This study aims to determine the effect of Padang's city branding (Presence, Place, potential, Pulse, People, Pre-requisite) towards its city image (cognitive, affective, conative) and tourist visit decision. Moreover, city image is also placed to be intervening variable between city branding and tourist visit decision. Based on the tourist data collected by survey (200 samples), structural equation modeling using Smart PLS 3.0 and Sobel Test were employed to test the research model. The findings indicate that the relationship in purposed model are significant. For researchers this study provides a basis for further development of city banding of Padang. For government and destination marketing organization (DMO), understanding the key construct is crucial to increase visitors and better perceived city image.
\end{abstract}

Keyword: City Branding, City Image, Visit Decision, Padang

\section{INTRODUCTION}

Tourism is widely recognised as an economic driving sector in the world. It is expected that the arrivals of international tourist will be increased by 3.3\% per year during 2010 until 2030 to reach 1.8 billion by the end of this period (UNWTO, 2017). This forecast is undoubtedly an opportunity for tourism potential countries such as Indonesia.

A number of destination in Indonesia has been aggressively developing the tourism sector of the region. One of the popular method is to create the destination brand. Brand for a destination is commonly referred as Place Branding or City Branding. Simon Anholt (as cited in Moilanen \& Rainisto, 2008) defined city branding as the image management of a destination through strategic innovation, economic, commercial, social, cultural, and governmental coordination. 
Padang is a center of government administration and business for West Sumatra province, one of the most popular tourism destination for local and international. The achievement of this province is widely acknowledge such as winning three categories of World Halal Tourism Award in 2016 which are; World's Best Halal Culinary Destination, World's Best Halal Destination and Halal World's Best Tour Operator. Hence, to improve its tourism sector, the government of Padang has prepared a brand of its own that is, "Padang Your Motherland".

The mentioned above tagline represents the uniqueness of Padang City as the capital of West Sumatra which possess Minangkabau matrilineal society. Using this brand, Padang City positions itself as a tourist destination that offers two main elements: Firstly, Padang has a unique culture in governing the way of life of its community members. Minang people in Padang still practice matrilineal system where the children hold their mother family name. This system is only embraced by five tribes in the world. It is represented through the slogan "your motherland". Secondly, Minangkabau tribe consist of various sub-ethnics (suku) that mingle in Padang City. This makes the City rich in diversity of customs, food, games and traditional crafts. This diversity is symbolised by the roof of Rumah Gadang and the various colors that decorate the brand (http://tourism.padang.go.id/).

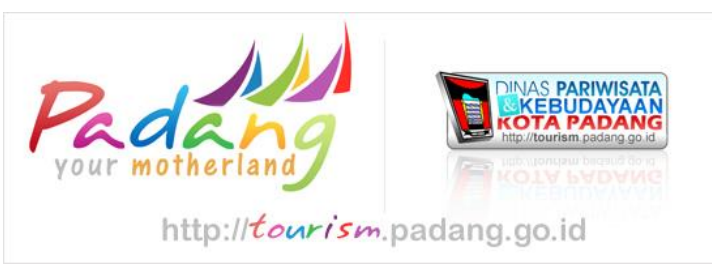

Figure 1. Padang City Logo and Brand

There are various events that held frequently by the city government to attract tourists, such as Minangkabau Halal Tourism Fair, Anak Nagari Festival, Sampan Race Competition, Siti Nurbaya Festival, Tour de Singkarak, Dragon Boat Internasional Festival, and Minangkabau Culinary Festival. These events are capitalised to improve the image of Padang. Based on the study and various potentials owned by Padang, the researchers are interested to study on how does the city branding affect the City image and tourist visit decision.

\subsection{Consumers Purchase Decision}

Purchase decision is a consumer behavior after obtaining desired product information, making judgments and establishing one option which is considered as the most beneficial. In tourism, purchase decision is equal to visiting decisions so that theories about purchase decision are adapted for visit decision (Wandari \& Ayu, 2014; Aqmarina, Kumadji, \& Kusumawati, 2016). 
City Branding

According to Simon Anholt as cited in Moilanen \& Rainisto (2008), City Branding is the image management of a destination through strategic innovation, and economic, social, commercial, cultural, and governmental coordination. Kavaratzis (as cited in Chaerani, 2011) divided city branding in the context of city image communication into three stages of communication: primary, secondary and tertiary. This study uses city branding hexagon as an evaluation standard of city branding. City branding hexagon was created by Simon Anholt to measure the effectiveness of city branding (Chaerani, 2011). There are six parameters to evaluate the effectiveness of city branding which are: presence, potential, place, pulse, people, and prerequisite.

\subsection{City Image}

City image is highly related to the beliefs, ideas and impressions of a place. Image is a view or perception of one person about a product or company. Image represents a simple generalization of the information associated with the place (Kotler, as cited in Salampessy, Suroso, \& Wulandari, 2015). According to Janes as cited in Salampessy et al. (2015), there are three dimensions to measure destination image; cognitive, affective, and conative. The cognitive dimension is related to trust and knowledge. The affective dimension measures an aspects of emotional value. Conative dimension discusses about the behavior associated with the destination (Barbara Janes as cited in Salampessy et al., 2015). Beside Barbara Janes, Koerte (2009) also defined cognitive, affective, and conative aspects as the image measurement.

Research Hypothesis

Based on background and literature review, the authors formulate the research hypothesis as follows:

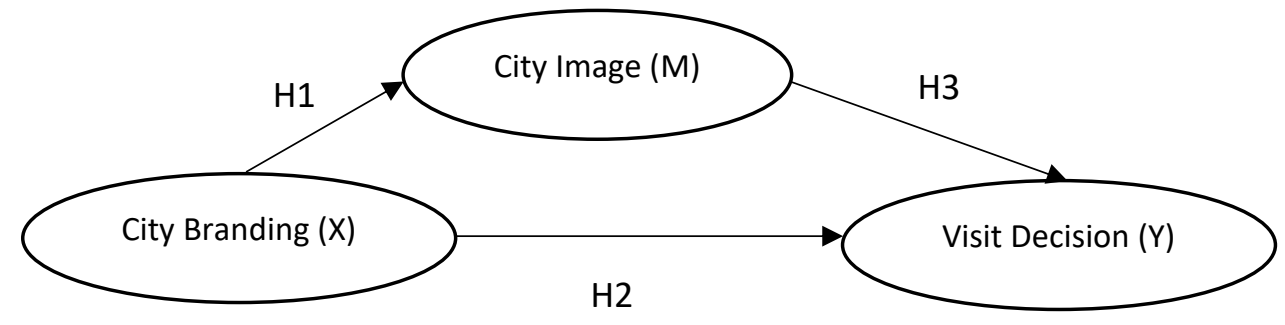

Figure 2. Research Hypothesis

H1: There is a significant positive influence of city branding on city image.

$\mathrm{H} 2$ : There is a significant positive influence of city branding on visit decision.

H3: There is a significant positive influence of city image on the visit decision.

H4: There is a significant positive influence of city branding on visit decision through city image as intervening variable. 


\section{RESEARCH METHOD}

This study measured the effect of exogenous variables on endogenous variables. Data collection is conducted in some tourism destinations in Padang. The research sample is 200 respondents. Data collection technique is purposive sampling with criterion:

1. Local tourists who have been and / or willingly visit Padang.

2. Travelers who know the brand or the slogan of Padang.

3. Tourists who know the tourism attractions in Padang.

Data were collected using questionnaires and analysed using Partial Least Square Structural Equation Modeling (PLS-SEM) and Sobel Test to test the mediation effect. The pilot test of the questionnaire shows that the questionnaire is valid and reliable.

\section{RESULTS AND DISCUSSION}

\subsection{Validity and Reability}

This research uses SmartPLS software version 3.0. Figure 3 shows that the value of factor loading indicators of each latent variables is greater than 0.7 . The test result on Table 1 shows that the value of Average Variance Exceeded (AVE) in the research is higher than 0.5. This means that any latent variables are eligible as good discriminant validity measurement.

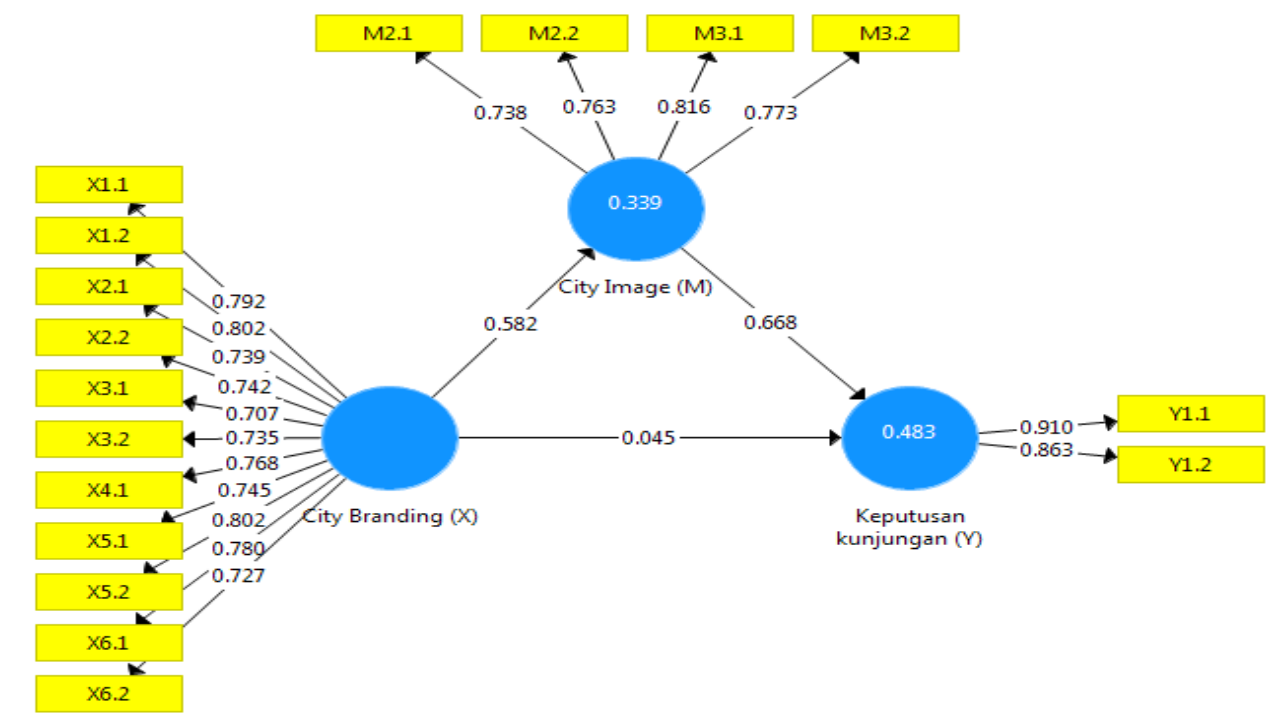

Figure 3. Factor Loading 
Table 1

Discriminant Validity Test

\begin{tabular}{lll}
\hline Variabel & AVE & $\begin{array}{l}\text { AVE } \\
\text { Quadrat }\end{array}$ \\
\hline City Branding & 0.576 & 0.759 \\
\hline City Image & 0.597 & 0.773 \\
\hline Visit Decision & 0.786 & 0.887
\end{tabular}

If AVE square root value of each construct is greater than the correlation value between the construct and the other constructs in the model, it is classified as good discriminant validity (Fornell and Larcker, 1981 as cited in Ghozali, 2006). Table 2 shows the value of AVE square is more than the value correlation between the constructs.

Table 2

Fornell-Larcker Test

\begin{tabular}{llll}
\hline & City Branding $(\mathrm{X})$ & City Image $(\mathrm{M})$ & Visit Decision $(\mathrm{Y})$ \\
\hline City Branding $(\mathrm{X})$ & 0.759 & & \\
\hline City Image $(\mathrm{M})$ & 0.582 & 0.773 & \\
\hline Visit Decision $(\mathrm{Y})$ & 0.434 & 0.694 & 0.887 \\
\hline
\end{tabular}

Table 3 shows the results of composite reliability test. It shows that the composite reliability values are greater than 0.7 . This indicates that all indicators can be used as measurement tools for each constructs.

Table 3

Composite Reliability

\begin{tabular}{ll}
\hline Variable & Composite Reliability \\
\hline City Branding & 0.937 \\
\hline City Image & 0.856 \\
\hline Visit Decision & 0.880 \\
\hline
\end{tabular}

Table 4 shows that cronbach's alpha value of all latent variables are above 0.7. it can be concluded that this research variables have fulfilled the reliability standard.

Table 4

\begin{tabular}{ll}
\multicolumn{2}{c}{ Croanbach's Alpha } \\
\hline Variabel & Croanbach's Alpha \\
\hline City Branding & 0.927 \\
\hline City Image & 0.775 \\
\hline Visit Decision & 0.731 \\
\hline
\end{tabular}


Table 5 shows that the value of $R$ Square of city image (0.339) is influenced by city branding and R Square value of visit decision (0.483) is influenced by city branding and city image.

Table 5

R Square Values of Variabel Endogen

\begin{tabular}{ll}
\hline Variabel Endogen & R Square \\
\hline City Branding & \\
\hline City Image & 0.339 \\
\hline Visit Decision & 0.483 \\
\hline
\end{tabular}

The predictive-relevance value is obtained by the formula:

$\mathrm{Q}^{2}=1-\left(1-\mathrm{R} 1^{2}\right)\left(1-\mathrm{R} 2^{2}\right) \ldots . .\left(1-\mathrm{Rp}^{2}\right)$

$\mathrm{Q}^{2}=1-\left(1-0,483^{2}\right)\left(1-0,339^{2}\right)$

$\mathrm{Q}^{2}=0,321$

The above result shows a predictive-relevance value is $0.321(>0)$. It can be interpreted that $32.1 \%$ variation in the variable explained by the variables used in the model. Other $67.9 \%$ is explained by other factors outside the model. Based on this results, it could be concluded that this model has a relevant predictive value.

\subsection{Hypothesis Testing}

Level of significance of relationship between latent variables could be determined from $\mathrm{t}$ statistic value. This value must be greater than t-table (1.96) for significant effect. Significant influence is a convincing or meaningful effect. In this study, it means that the hypotheses which have been compiled are proved.

Table 6

Path Coefficients

\begin{tabular}{lllllll}
\hline & $\begin{array}{l}\text { Original } \\
\text { Sample } \\
(\mathrm{O})\end{array}$ & $\begin{array}{l}\text { Sample } \\
\text { Mean } \\
(\mathrm{M})\end{array}$ & $\begin{array}{l}\text { Standard } \\
\text { Deviation } \\
(\text { STDEV) }\end{array}$ & $\begin{array}{l}\text { Standard } \\
\text { Error } \\
(\text { STERR) }\end{array}$ & $\begin{array}{l}\text { T-Statistics } \\
(\mid \mathrm{O} / \text { STERR } \mid)\end{array}$ & $\begin{array}{l}\text { Significance } \\
\text { Level }(1,96)\end{array}$ \\
\hline $\begin{array}{l}\text { City } \\
\text { Branding } \\
(\mathrm{X}) \rightarrow\end{array}$ & & & & & & \\
$\begin{array}{l}\text { City } \\
\text { Image } \\
(\mathrm{M})\end{array}$ & 0.582 & 0.589 & 0.051 & 0.051 & 11.454 & Significant \\
\hline $\begin{array}{l}\text { City } \\
\text { Branding } \\
(\mathrm{X}) \quad 0.045\end{array}$ & 0.053 & 0.067 & 0.067 & 2.672 & Significant \\
\hline
\end{tabular}




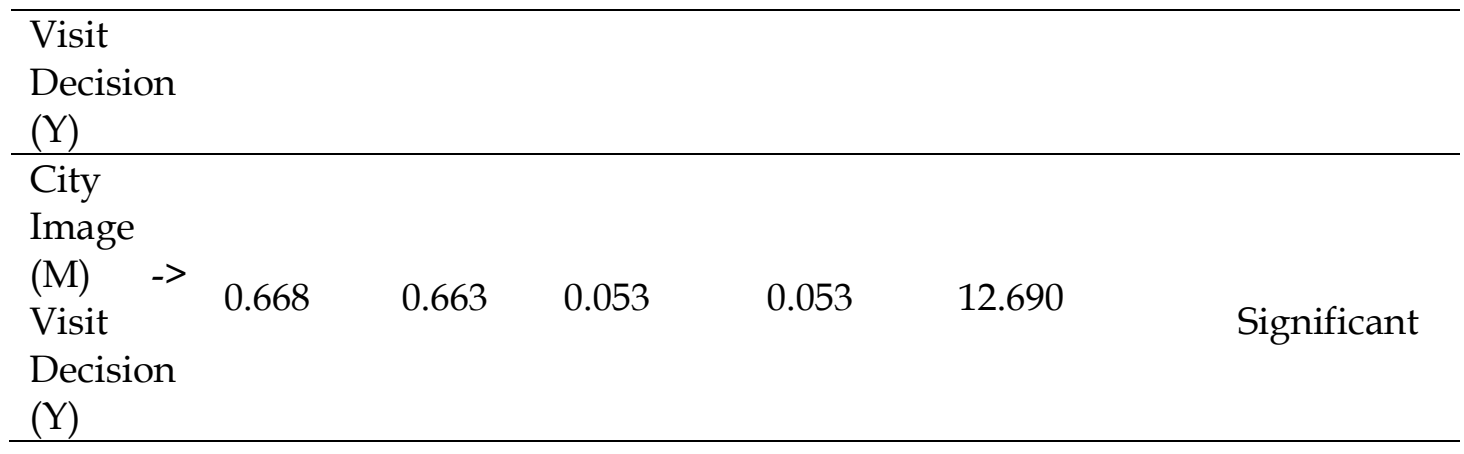

In PLS, statistical testing of each relationship is performed using a simulation. In this case, a bootstrap method is performed on the data sample. Testing with bootstrap is also intended to minimize the problem of research data abnormalities. According to Chin as cited in Ghozali \& Latan (2015), t-statistics should be greater than t-table (1.96) to concluded as significant.

The test results with bootstrapping from PLS analysis are as follows:

- Hypothesis 1: The influence of city branding on city image.

The results of hypothesis 1 test shows that the coefficient value of 0.582 lane with tvalue of 11.454. The value is greater than the t-table value (1.96). This result means that there is a significant positive influence of city branding on city image. The result of this study is relevant with Ivani (2015), which found that city branding has a positive and significant influence on the city image

- Hypothesis 2: The influence of city branding on visit decision.

The result of hypothesis 2 test shows that coefficient value of city branding to visit decision is 0.045 with $\mathrm{t}$-count equal to 2.672 . This value is greater than the $\mathrm{t}$-table value (1.96). The result means that there is a significant positive influence of city branding on visit decision. This findings is in agreement Wandari \& Ayu (2014) which states that there is a positive and significant influence between city branding on visit decision.

- Hypothesis 3: The influence of city image on visit decision

The result of hypothesis 3 test shows that coefficient value of city image to visit decision is 0.668 with $t$-count equal to 12.690 . This value is greater than the $t$-table value (1.96). The result means that there is a significant positive influence of city image on visit decision. This research result is similar with research result conducted by Ivani (2015) which states that there is a positive and significant influence between city image on visit decision.

- Hypothesis 4: The influence of city branding on visit decision through city image as intervening variable. 
The indirect effect test is conducted by Sobel Test formula. There are two steps in Sobel Test.

1. Determining the Indirect Effect Coefficient

Table 7

Indirect Variable Coefficient

\begin{tabular}{llll}
\hline Variabel & Symbol & Koefisien & $\begin{array}{l}\text { Standard } \\
\text { Error (S) }\end{array}$ \\
\hline $\begin{array}{l}\text { City Branding -> } \\
\text { City Image }\end{array}$ & a & 0,582 & 0,051 \\
\hline $\begin{array}{l}\text { City Image -> } \\
\text { Visit decision }\end{array}$ & b & 0,668 & 0,053 \\
\hline
\end{tabular}

$\mathrm{X} \rightarrow \mathrm{M}$ or a: result of multiplication of city branding variable to city image

$\mathrm{M} \rightarrow \mathrm{M}$ or b: result of multiplication of city image variable to visit decision

Sa: Error standard coefficient a

Sb: Error standard coefficient $b$

The value influence of indirect city branding coefficient on visit decision through city image is the multiplication of city branding influence on city image and city image on visit decision. So the coefficient result of indirect effect is 0.39 . This means that the impact of city branding on visit decision through the city image is $39 \%$.

2. Testing the Significance of Indirect Variables

The indirect effect shown by the multiplication coefficient $(a b)$ needs to be tested by Sobel test:

$$
\begin{aligned}
S a b & =\sqrt{b^{2} S a^{2}+a^{2} S b^{2}+S a^{2} S b^{2}} \\
& =0,046 \\
\mathrm{a} & =0.582 \quad \mathrm{~b}=0.668 \\
\mathrm{Sa} & =0.051 \quad \mathrm{Sb}=0.053 \\
\mathrm{ab} & =(0.582) \times(0.668)=0.39
\end{aligned}
$$

To calculate the $t$-value of indirect effect, this research used the following formula: $\mathrm{t}=\mathrm{ab} / \mathrm{Sab}$

$\mathrm{t}=0,39 / 0,046=8,48$

The $\mathrm{t}$-value (8.48) is greater than $\mathrm{t}$-table (1.96) which means there is a significant indirect influence of city branding on visit decision through city image. 


\section{CONCLUSION AND IMPLICATIONS}

This research result could summarized follows: 1) City branding statistically has an influence on the city image, which means that when the city branding is formed well then the city image of Padang will increase as well. 2) City branding statistically has an influence on visit decision, which means that better city branding will stimulate tourists' visit to the city. 3) City image also statistically influences visit decision. It means that the city with good image have more probability to be visited by tourists. 4) Furthermore, statistically there is indirect influence of city branding variable on the decision of visit through city image. This means that city branding will improve and form city image which will eventually increase the decision of tourist visit to padang city.

This study has important practical contributions. Firstly, the city branding of Padang should continue to be socialized to public through various media so that people understand the meaning of the brand of Padang "Padang Your Motherland". Second, in order to attract visitors, the government should continue to nurture, develop, and improve all aspects of Padang base on city branding. Third, government of Padang should increase the city image in order to create a strong image of Padang through active publications and interesting events.

\section{REFERENCES}

Aqmarina, S., Kumadji, S., \& Kusumawati, A. (2016), "Pengaruh Celebrity Endorser Terhadap Citra Merek Serta Dampaknya Pada Keputusan Pembelian (Survei pada Mahasiswi Fakultas Ilmu Administrasi Universitas Brawijaya Angkatan 2013 dan 2014 Konsumen Produk Kosmetik Wardah)". Jurnal Administrasi Bisnis, Vol.39, No.2, pp.110.

Chaerani, R. Y. (2011), "Pengaruh City Branding Terhadap City Image (Studi Pencitraan Kota Solo: 'The Spirit of Java')", Jurnal Riset Komunikasi, Vol.2, No.4.

Ghozali, I. (2006), Aplikasi Analisis Multivariate dengan Program SPSS (4th ed.)., Badan Penebit Universtas Diponogoro.

Ghozali, I., \& Latan, H. (2015), Partial Least Squares, Konsep, Teknik dan Aplikasi Menggunakan Program Smartpls 3.0 untuk Penelitian Empiris, Badan Penerbit UNDIP, Semarang.

Ivani, S. Z. N. (2015), "Pengaruh City Branding “Enjoy Jakarta" terhadap Citra Kota dan Keputusan Berkunjung Youth Traveller ke Jakarta", UIN Syarif Hidatullah.

Koerte, T. R. (2009), "The Projected and Perceived Image of the United Republic of Tanzania", CFS Honors Program Undergraduate Theses, available at: 
https://docs.lib.purdue.edu/cfstheses/8

Moilanen, T., \& Rainisto, S. (2008), "How to Brand Nations, Cities and Destinations: A

Planning Book for Place Branding. How to Brand Nations, Cities and Destinations: A

Planning Book for Place Branding", Palgrave Macmillan, available at:

https://doi.org/10.1057/9780230584594

Salampessy, H., Suroso, I., \& Wulandari, D. (2015), "Pengaruh City Branding terhadap City Image, Customer Satisfaction, Dan Customer Loyalty Di Kota Ambon", Jurusan

Manajemen Fakultas Ekonomi Dan Bisnis, Vol.9, No.2, pp.134-144.

UNWTO (2017), "UNWTO Tourism Highlights 2017 Edition", available at:

https://doi.org/10.18111/9789284419029

Wandari, \& Ayu, L. (2014), "Pengaruh City Branding “Shining Batu” Terhadap City Image

Dan Keputusan Berkunjung Wisatawan Ke Kota Batu Tahun 2014", Jurnal Administrasi Bisnis, Vol.16, No.1. 